
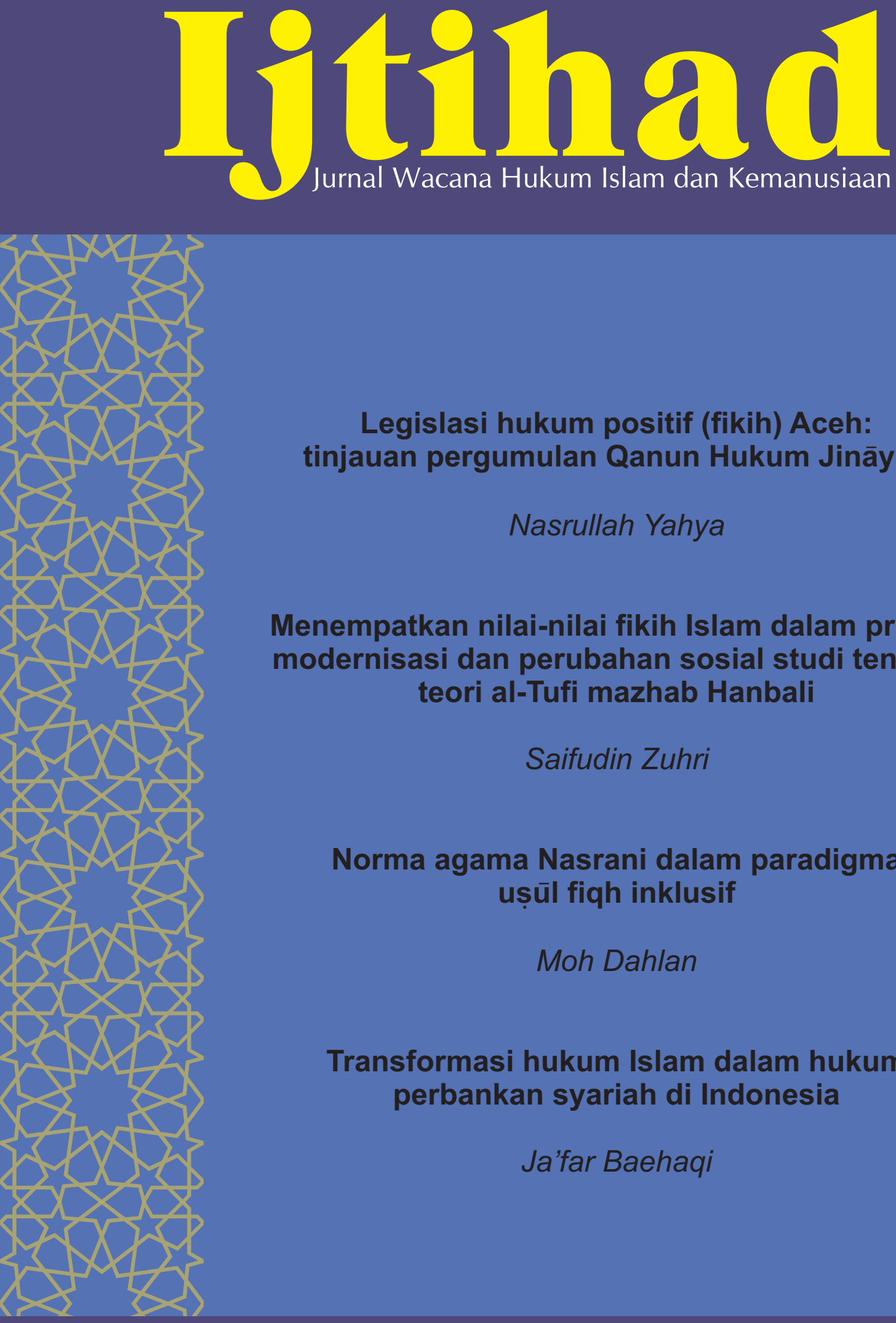

Legislasi hukum positif (fikih) Aceh: tinjauan pergumulan Qanun Hukum Jināyāh

\author{
Nasrullah Yahya
}

Menempatkan nilai-nilai fikih Islam dalam proses modernisasi dan perubahan sosial studi tentang teori al-Tufi mazhab Hanbali

Saifudin Zuhri

Norma agama Nasrani dalam paradigma ușūl fiqh inklusif

Moh Dahlan

Transformasi hukum Islam dalam hukum perbankan syariah di Indonesia

Ja'far Baehaqi 


\section{Ijtihad \\ Vol. 14, No. 2, Desember 2014}

\section{Daftar isi}

Legislasi hukum positif (fikih) Aceh: tinjauan pergumulan Qanun Hukum Jināyāh

Nasrullab Yabya • 149-166

Menempatkan nilai-nilai fikih Islam dalam proses modernisasi dan perubahan sosial studi tentang teori al-Tufi mazhab Hanbali

Saifudin Zubri • 167-187

Norma agama Nasrani dalam paradigma uṣūl fiqh inklusif

Mob Dablan • 189-209

Transformasi hukum Islam dalam hukum perbankan syariah di Indonesia Ja'far Baehaqi • 211-230

Akar, posisi, dan aplikasi adat dalam hukum

Abwan Fanani - 231-250

Bayang-bayang teori keagenan pada produk pembiayaan perbankan syariah Misnen Ardiansyah • 251-269

Dimensi politik hukum dalam perkembangan ekonomi Islam di Indonesia Bambang Iswanto • 271-284

Book Review:

Kritik otoritas pemaknaan hadis menuju masyarakat Islam berkemajuan Mubammad Irfan Helmy • 285-297 



\title{
Menempatkan nilai-nilai fikih Islam dalam proses modernisasi dan perubahan sosial studi tentang teori al-Tufi mazhab Hanbali
}

\author{
Saifudin Zuhri \\ Fakultas Ilmu Tarbiyah dan Keguruan (FITK) LAIN Walisongo Semarang \\ E-mail:saifudinzubri71@gmail.com
}

Al-Tufi intellect in the field of usuul fiqh impressed liberals and generalist, pure of logical thinking and the knowledge he gained from many cities and many Muslim theologians. No change in the system of theology. Maṣlahah concept used instead ra'yu free without limit, but methodological step with existing laws, customs used by the companions of the Prophet Umar, may Allah be pleased, and Imam Malik. The methodology used is bayān (exegesis) also taqyid and tạ̣ $\overline{d i d}$ an-naṣ. Being based on bayān (exegesis) also taqyid and taḥdid an-naș and custom law, their values are as implemented by the method of ijtihad takhșiș munfașil. It is used as a method to cope with the statement of the Koran that seem contradictory to each other. The goal is to create distance and theistic concept of fiqh imperative at that time, by directing the point of view of jurisprudence that not only theological but also humanistic.

Intelektualitas Al-Tufi dalam bidang ușül fiqh terkesan liberalis dan generalis, murni dari pemikiran logis dan pengetahuan ia peroleh dari banyak kota dan banyak teolog muslim. Tidak ada perubahan dalam sistem teologinya. Konsep maslahah yang digunakan bukan ra'yu bebas tanpa batas, namun metodologis melangkah dengan hukum yang ada, kebiasaan yang digunakan oleh sahabat Nabi Umar, ra. dan Imam Malik. Metodologi yang digunakan adalah bayān (penafsiran) juga taqyid dan tahdid annaṣ. Dengan berbasis kepada bayān, taqyid dan tahđi $\mathrm{d}$ an-naṣ dan hukum adat, nilai-nilai mereka adalah seperti yang diterapkan oleh metode ijtihad takh munfașil. Hal ini digunakan sebagai salah satu metode untuk mengatasi pernyataan dari Al-Quran yang tampak kontradiktif satu sama lain. Tujuannya untuk membuat jarak konsep fikih imperatif dan teistik pada waktu itu, dengan mengarahkan titik pandang fikih yang tidak hanya secara teologis tetapi juga humanistik.

Keywords: Mașlahah; Ratio; Ijtihad; Culture; Exegesis 
Ijtihad, Jurnal Wacana Hukum Islam dan Kemanusiaan, Volume 14, No. 2, Desember 2014: 167-187

\section{Pendahuluan}

Dengan meluasnya lingkup perubahan sosial yang mempengaruhi semua segi kehidupan, di mana pola kehidupan utilitarian menjadi popular, maka gerakan-gerakan modernisme dalam hukum Islam gigih berusaha mencari landasan atau pijakan yang mampu membantu mereka menyesuaikan diri dengan kondisi-kondisi yang berubah. Mereka menemukan landasan itu dalam teori maṣlahah . Karena itu perhatian ilmiah dicurahkan untuk mengkaji teori mașlaḥah ini.

Pada tahun 1867 Khaerudin Phasa dalam kitabnya Aqwam al-Mamālik mengukuhkan kembali bahwa prinsip maṣlaḥah harus menjadi pedoman tertinggi pemerintah. Ini sangat penting karena bisa dipakai untuk membenarkan perubahan lembaga-lembaga demi kepentingan umum (Muslim World, 1980: 164). Pada tahun 1899 Muhammad Abduh dalam pidatonya tentang pembaruan-pembaruan sistem peradilan di Mesir dan Sudan, menekankan juga tentang penggunaan mas $\}$ lah \} ah sebagai prinsip pembimbing dalam pembuatan hukum (Abduh, 1899 : 761).

Schacht (1899: 761J) menyatakan bahwa prinsip maṣlaḥah menurut 'Abduh, lebih disukai dari pada penerapan hukum Islam secara harfiah (Schacht, 1961: 406). Henry Laoust, sebagaimana dikutip J. Schacht juga menyatakan bahwa prinsip mas $\}$ lah $\}$ ah adalah salah satu dari dua gagasan yang mendasar atasnya. Abduh memandang Islam lebih unggul dari pada Kristen. Karena prinsip ini pulalah Islam memiliki kesadaran akan realitas secara lebih maju dari pada Kristen. Khairuddin dan 'Abduh kedua-duanya menyebut mas \}lah\}ah sebagai prinsip penafsiran hukum dan dengan demikian juga merupakan prinsip perubahan, dinamisme dan adaptabilitas.

Sejumlah besar sarjana muslim modern di bidang hukum Islam seperti: Rasyid Rida, Subhi Mahmasani, 'Abdul Razzaq as-Sanhuri, Ma'ruf ad-Duwalibi, Mustafa al-Shalabi, 'Abdul Wahhab Khallaf, Muhammad al-Khudari dan Mustafa Abu Zaid (Dualibi,1965: 442). Mereka sangat apresiatif terhadap implementasi maṣlahah, lebih kurang sejalan dengan konsep alTufi.

Eksistensi teori al-Tufi semakin kuat seiring dengan hermeneutika sebagai salah satu metode penafsiran al-Qur'an. Ketika teks al-Qur'an dibaca, dipahami, ditafsirkan dan ditakwilkan oleh para mufasir dan oleh siapapun juga, maka hermeneutika selalu muncul 
dan memang tidak perlu dihindari (Edwards (ed),1972: 489-490). Memang, pada mulanya al-Qur'an adalah kalam Allah yang tanpa suara dan huruf, (Nasution, 1987: 143-144). Namun, al-Qur'an yang kita baca sekarang adalah sebuah teks dengan memilih bahasa Arab sebagai sarana komunikasinya (Hazm,1996: 38-43).

Kita yakini al-Qur'an besumber dari zat yang metafisis, transendental, pesan dan makna yang dikandungnya tiada lain untuk manusia. Karena itu penggaliannya tidak terlepas dari ra'yu manusia, yang tidak mungkin menggunakan metode khusus sesuai dengan realitas ra'yu ketuhanan. Teks al-Qur'an dikukuhkan dengan ketentuan Tuhan yang absolut-eternal (naș Ilahi), namun teks tersebut dihadapkan kepada manusia (teks insani) sejak masa awal diturunkannya yang kemudian diikuti pembacaannya oleh Muhammad saw. Pembacaan yang berarti pemahamannya merupakan bentuk paling awal persentuhan teks dengan ra'yu manusia. Di saat sebuah teks telah berhadapan dengan ra'yu manusia, maka sifat sakral dan absolutnya hanya ada pada zat Tuhan, yang pada ra'yu manusia menjadi sesuatu yang bersifat ijtihādi (Hazm, 1964: 38-43).

Sebagaimana Abdullah Darraz mengatakan, bahwa lafaz redaksional al-Qur'an adalah hammalah li al-wujūh (Darraz,1966: 110-111). Makna pesan Allah yang terkandung dalam teks al-Qur'an, tidak terlepas dari daya tangkap para mufasirnya tidak sama persis dengan apa yang dikehendaki Allah, karena memang ra'yu manusia tidak akan sampai ke sana. Lebih-lebih bila dikaitkan dengan ruang dan waktu antara keduanya telah lama dan jauh berbeda, dan lebih-lebih lagi Allah tidak mempunyai ruang dan waktu.

Ketiga unsur, pemberi wahyu (Allah), teks al-Qur'an dan manusia (interpreter), atau istilah lain, tujuan, teks dan tafsîr tidaklah mungkin dipadukan secara hakiki. Karenanya makna teks al-Qur'an berada dalam teks, ra'yu pengarang dan ada pada ra'yu pembacanya. Istilah lain, in the world of the text, the world of author and the world of reader. Ketiga unsur ini harus benar-benar diperhatikan karena bisa menjadi pembantu dan pada waktu yang sama bisa membelokkan dalam memahami makna suatu teks naṣ (Supena 2002: 258).

Dari segi mantūqnya, redaksinya bersifat tetap (thäabit), tetapi dari segi mafhüm terhadap redaksionalnya bisa bersifat mutaharrik- mutaghayyir. Sifat tetap dan berubahnya suatu nas melekat pada setiap nas sejak pembuatannya sudah dikodifikasikan. Seperti nas al-Qur'an. Sedangkan yang periwayatannya melalui lisan ke lisan, meskipun hanya selang beberapa 
ljtihad, Jurnal Wacana Hukum Islam dan Kemanusiaan, Volume 14, No. 2, Desember 2014: 167-187

waktu, seperti hadis Nabi, maka akan menimbulkan multi tafsîr terhadap isi redaksionalnya, dan juga menimbulkan kesamaran dari segi wurüdnya (Thalib, 1979: 20). Nas-nas semacam ini tetap mengundang perselisihan tentang kejelasan dan kesamaan makna yang dikandungnya. Ditegaskan oleh Abu Zaid, terks itu telah kehilangan sifat permanennya meskipun dalam bentuk redaksionalnya, dan karena itu menjadi garapan ijtihād (Zayd, 1994: 119).

\section{Rancang bangun teori maṣlaḥah al-Tufi}

Al-Tufi mengartikan mașlaḥah sebagai: Sebab yang membawa dan melabirkan kebaikan dan manfaat yang sejalan dengan tujuan syar̈i baik yang berkaitan dengan ibadah maupun müamalah (alTufi,1009:138). Maslahah sebagai suatu metode ijtihad untuk menetapkan hukum bertujuan mencapai kemaslahatan umat, serta untuk menghindarkan dari kemafsadatan, tolak ukurnya bukan saja dikembalikan nas syara', melainkan juga dikembalikan pada akal manusia yang berupa kebiasaan-kebiasaan yang ada (adat). Bahkan suatu ketika maslaḥah harus didahulukan dari pada nas dan Ijma', karena ia memandang maslahah adalah dalil yang terkuat. Bertolak dari sinilah, al-Tufi membangun teori maslaḥah melalui 4 asas, yaitu:

Asas yang pertama

$$
\text { استقلال العقول بادراك المصالح والمفاسد. }
$$

"Akal semata (tanpa konfirmasi Naṣ) dapat mengetahui kebaikan dan keburukan".

Al-Tufi berpendapat akal manusia mampu mengetahui kebaikan dan keburukan dalam persoalan muamalah dan adah (hukum adat). Ia mengatakan (Hamid, 1971: 543-547):

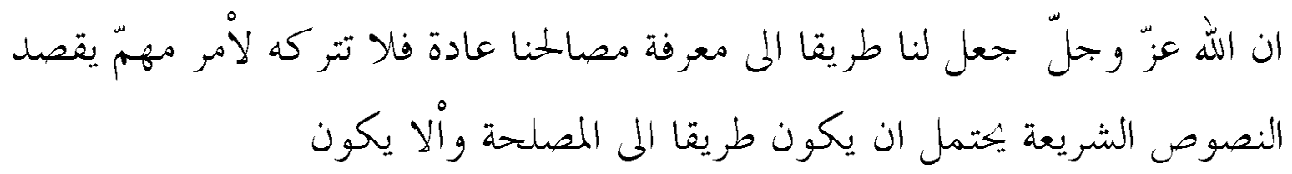

Lebih lanjut al-Tufi mengatakan (al-Tufi, 1993: 143-144):

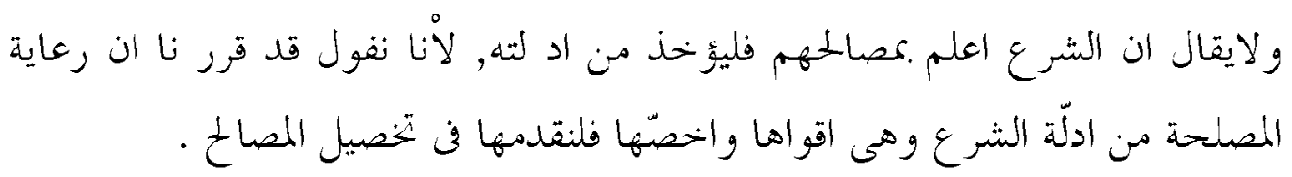


Menempatkan nilai-nilai fikih Islam dalam proses modernisasi dan perubahan sosial...(Saifudin Zuhri)

ثم انّ هذا انما يقال في العبادات التئت تخفى هصالحها عن بمارى العقول والعادات. اما مصلحة سياسة المكلفّين في حقوقةم فهى هعلومة لمم بككم العادة

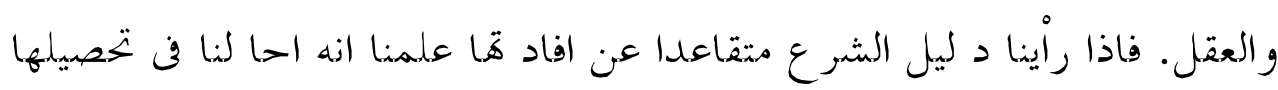

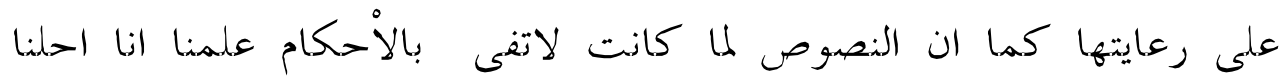

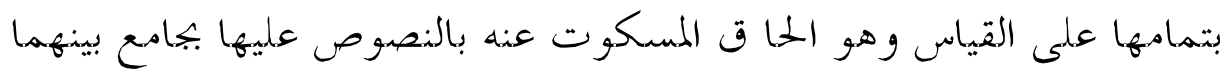
Asas yang kedua ( Hamid, 1971:. 543-547):

$$
\text { المصلحة د ليل شرعى مستقل ثن النصوص }
$$

"Maṣlaḥah merupakan dalil syara' mandiri yang kehujjahannya tidak tergantung (pada kesaksian) naṣ".

Ketika akal itu mampu mengetahui kebaikan, tentu maslaḥah mampu berdiri sendiri sebagai hujjah, tidak harus ada konfirmasi nas. Al-Tufi menyatakan bahwa batasan maṣlaḥah itu adalah al'Urfu (al-Tufi, 1993: 241). Menurut kami (al-Tufi,1993: 241):

أن رعايتها 3 ذلك (غير العبادات) هي تطب مقعود الشرع منها, بخلا ون العبادات

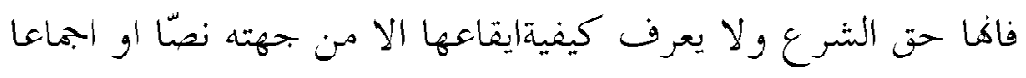

Al-Tufi secara tegas menyatakan (al-Tufi, 1993:274):

واعلم أن هذه الطريثة التي قررناها مستغيد ين من الملد يث المذا كور ليست هي (a) القول بالمصلح المرسلة على ماذ هب اليه ماللك, بل هى ابلغ من ذلك وهى التأويل

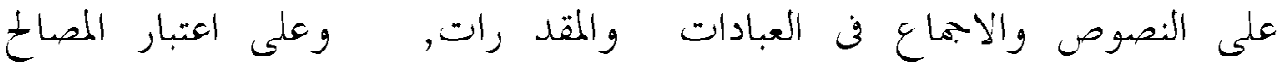
فيالمعاملانت وباقى الاحكام

Al-Tufi berkesimpulan (al-Tufi, 1999, jilid 1: 142-143):

هذا دليل قوي لا يتجه القدح فيه ولا يرد عليه ما ذ كر من المنع من زراعة العنب ونغوه اذ هو مصلحة لا نا نقول : هذه مصلحة نص الشرع على عدم اعتبارها

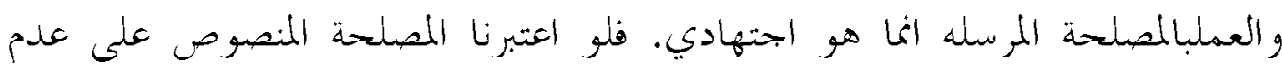

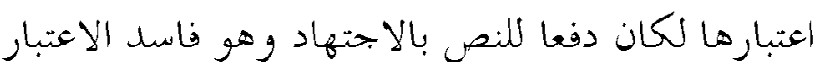


ljtihad, Jurnal Wacana Hukum Islam dan Kemanusiaan, Volume 14, No. 2, Desember 2014: 167-187

Asas yang ketiga (al-Tufi, 1998: hlm. 241):

$$
\text { بال العمل بالمصلحة هو المعاملات و العادات }
$$

"Ruang lingkup beramal dengan maṣlahah adalah pada bidang muamalat dan adat."

Al-Tufi menegaskan, jika hukum-hukum yang menyangkut ibadah, maka dalil yang diakui adalah nas, Ijma' dan sumber hukum lainnya, tetapi jika berkaitan dengan muamalah dan yang sejenis, ia menegaskan (al-Tufi, 1945: 277):

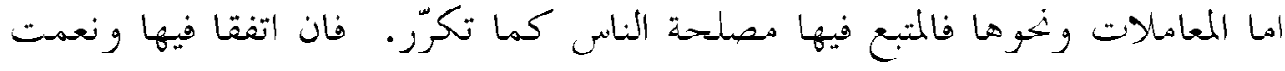

$$
\begin{aligned}
& \text { كما اتفق النص والاجماع والمصلحة غلى اثبات الاحكام الخمسة الكلية الضرورية, }
\end{aligned}
$$

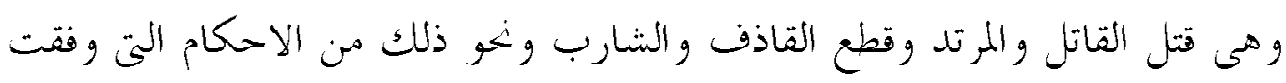

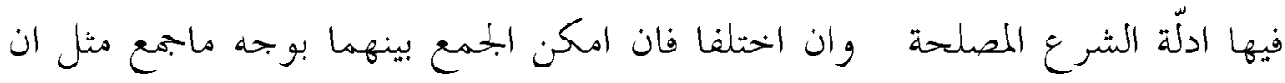

$$
\begin{aligned}
& \text { يجمل بعض الادلة على بعص الاحكام او الاحوال دون بعص على وجه لايخل } \\
& \text { بالمصلحة ولا يفضى الى التلاعب بالادلة او بعضها. فان تعنر الجمعع قدمت المصلحة }
\end{aligned}
$$

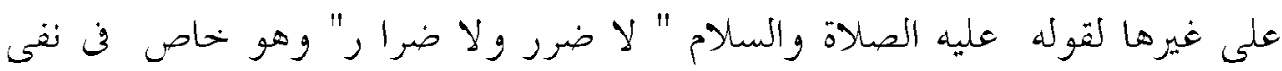

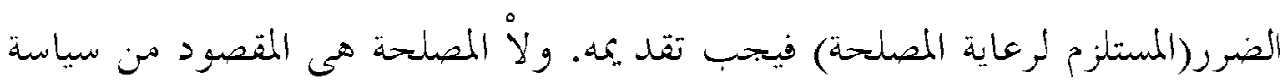

$$
\begin{aligned}
& \text { المكلفين ( بائبات الاحكام) وباقى الادلة كالوسائل, و والمقصود واجبةالتقد يم على } \\
& \text { الو سائل . }
\end{aligned}
$$

Terkait dengan hukum-hukum ibadah, sungguhpun yang diakui adalah naș, ijma’ dan dalil-dalil lainnya, tetapi bukan berarti tidak ada ijtihād, seperti dalam kasus yang terkait sabda Rasulullah ketika selesai perang ahzab, "Jangan kalian melakukan salat asar melainkan setelah sampai di Bani Quraidah". Ternyata ada sebagian sahabat yang melakukan salat asar sebelum sampai di Bani Quraiḍah. Al-Tufi menyatakan: Dalil-dalil ibadah adakalanya satu dan menyatu, dan adakalanya banyak dalilnya. Kalau dalil itu menyatu seperti dalam suatu masalah ada dalil ayat al-Qur'an, Hadis atau Qiyas dan lain-lainnya, maka hukum itu ditetapkan sesuai dengan pengertian salah satu dalil tesebut. Dan jika dalilnya banyak, misalnya dalam satu masalah terdapat dalil dari al-Qur'an, Hadis, Qiyas, Istishab dan lainnya, kalau dalil-dalil itu senada baik unsur positif maupun negatifnya, maka hukum 
itu ditetapkan bedasarkan dalil-dalil itu. Tetapi apabila dalil-dalil itu terdapat kontradiksi dalam menghadapi suatu masalah, kemungkinan bisa dikompromikan dan adakalanya tidak bisa dikompromikan. Bila mungkin dikompromikan, harus dikompromikan, karena sesungguhnya dalil-dalil itu untuk diamalkan, bukan digugurkan. Sungguhpun demikian cara mengkompromikan harus dengan jalan yang bijaksana, saling mendekatkan dan jelas. Tidak terkesan mempermainkan dalil-dalil syara'. Pada gilirannya, kalau ternyata tidak bisa dikompromikan, ijma' harus didahulukan dibanding dalil-dalil lain, dan dalil naṣ harus didahulukan dibanding dalil-dalil lain selain ijma'(al-Tufi, 1945:274-275).

Asas yang keempat

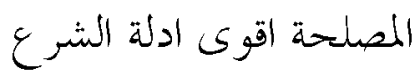

"Maṣlaḥah adalah dalil syara' terkuat."

Dalil-dalil syara' menurut al-Tufi baik yang telah disepakati maupun yang masih diperselisihkan para ulama usul, berjumlah 19. Setelah diadakan penelitian, semua pendapat ulama telah tercakup di dalamnya. Kesembilan belas itu adalah: (1) al-Kitab, (2) al-Sunnah, (3) Ijmā' al-Ummah. (4) Ijmā' abl al-Madinah, (5) al-Qiyass, (6) Perkataan Sahabat Rasul, (7) AlMașälị̣ al-Mursalah, (8) al-Istisḥāab, (9) Al-Barāah al-Așliyyah, (10) al-'Awäid, (11) Istiqra; (12) Saddu al-Zariah,(13) Istidlal, (14) al-Istiḥsān, (15) al-Akhdh bi al-akhaff (mengambil yang lebih ringan), (16) al-Ismah, (17) Ijmà' abl al-Küfah, (18) Ijmä', abl al-Itrah (keluarga Nabi, dan (19) Ijmä, al-Khulafáa al-Räshidīn (al-Tufi,1945: 237).

Dari 19 dalil tersebut, dalil yang terkuat adalah nas dan Ijma'. Keduanya ini terkadang selaras dan terkadang bertentangan dengan maṣlaḥah. Jika selaras, maka dalil maṣlaḥah tidak perlu dipertentangkan lagi, karena sudah ada kesepakatan tiga dalil sekaligus (nas, ijma' dan maṣlahahah) bagi suatu peristiwa hukum berdasarkan hadis la ḍarara tersebut. Jika antara keduanya bertentangan, maka maṣlahạah harus didahulukan dengan metode tahșị dan tabyin, bukan dengan cara meninggalkan atau membekukan keduanya. Seperti mendahulukan alSunnah atas al-Qur'an dengan cara bayan (al-Tufi, t.t:107-109). Al-Tufi menyatakan (al-Tufi dalam Wahab 1972: 107-108):

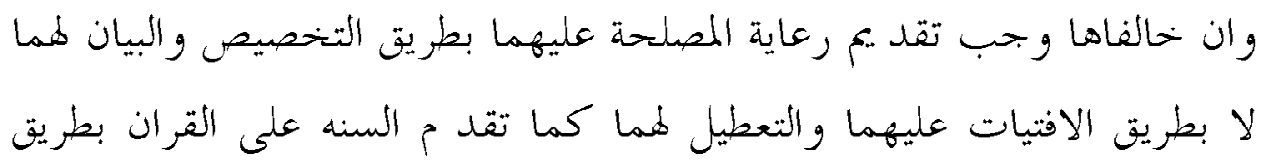


(al-Tufi, t.th.: hlm.107-109)

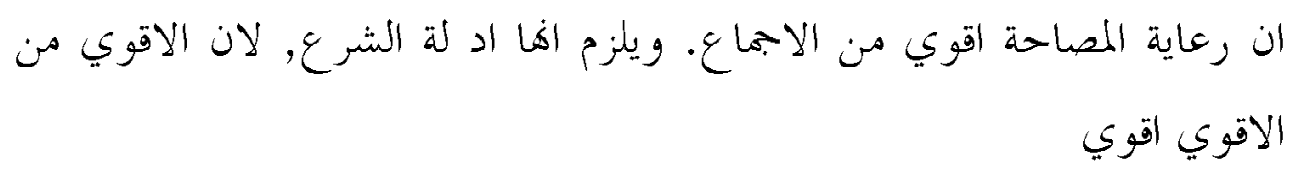

Al-Tufi hanya mengakui ijma' dalam bidang ibadah dan yang sejenis, seperti hukum ḥad, qișas atau hukum lain yang telah ditentukan rinciannya yang memang tidak bisa diketahui kecuali dari nas atau yang menjadi pegangan nas.

\section{Pengaruh teori mașlahahah di Indonesia}

Dalam sejarah perkembangan pemikiran telah nyata bahwa tidak ada suatu konsep yang lahir dalam posisi fitrah tanpa pengaruh ruang, waktu maupun pemikiran seseorang. Pemikiran hukum Islam di kalangan ulama Indonesia juga mengalami proses seperti ini. Artinya ada pihak-pihak tertentu yang mempengaruhinya. Paling tidak untuk mengukur keabsahan pengaruh itu adalah dengan cara meneliti corak pemikiran para ulama maupun suasana religius yang berkembang di Indonesia

Dari hasil kajian ini, ijtihad dan pemikiran at-Ṭ̂́fi ini berpengaruh menimbulkan dua corak gerakan yuristik: Pertama, Dari yang khusus kepada yang umum. Dari yang pertama ini melahirkan kajian latar-belakang dimana ketentuan naṣ itu diwahyukan sehingga dapat diketahui ditetapkannya Shari'at itu bertujuan untuk membeck up kemaslahatan pada waktu itu. Dalam pada itu apabila kemaslahatannya berbeda karena perbedaan durüf, penafsiran teks wahyu dapat disesuaikan.

Kedua, dari yang umum kepada yang khusus. Dari kajian kedua, ini melahirkan pemikiran bahwa situasi dan kondisi kontemporer juga harus dikaji agar prinsip-prinsip penerapan hukum Islam tidak terlepas darinya. Artinya kondisiriil masyarakat menjadi pertimbangan penting di dalam isbāt al-ḥukm sehingga bisa saja maṣlaḥah didahulukan dari pada nas. Dari dua gerakan yuristik ini bermuara ujungnya pada pembaharuan metodologi hukum Islam menuju fiqh kontekstual yang tidak terlepas dari akar budaya masyarakat.

Disinyalir oleh Syafruddin Prawiranegara bahwa kesalahan umat Islam selama ini adalah tidak mengakui kebebasan berpikir. Dia menolak pembatasan ijtihād dengan tidak boleh menyimpang dari bunyi tekstual hadis. Menurutnya, hadis itu hanya pendapat manusia biasa 
yang relatif, dan hanya terbatas pada ruang dan waktu yang dikenalinya. Sebagai contoh keterangan Nabi tentang zakat hanyalah berlaku bagi type masyarakat abad ke-7, atau abad lain yang type masyarakatnya mempunyai kesamaan. Peraturan zakat yang diderivasi dari alQur'an dan hadis, seperti kewajiban zakat kurma, unta dan lain-lain hanyalah cocok buat masyarakat yang sederhana. Apabila ketentuan semacam ini sekarang harus diterapkan secara leterlijk, maka orang zaman sekarang harus tetap naik delman, dan tidak boleh naik mobil (Prawiranegara, 1978: 4-15).

Gagasannya tentang reaktualisasi ajaran Islam sejak tahun 1985 dalam berbagai kesempatan sosialiasi, berulang kali Munawir Sjadzali mengutip maṣlaḥah al-Tufi. Dan ternyata mulai tahun 90-an mulai mendapatkan sambutan hangat dari berbagai ulama di Indonesia, utamanya reaktualisasi hukum Islam dalam bidang perbankkan. Kini telah lahir UU No. 21 Tahun 2008 tentang Perbankan Shariah, Munawir Sadzali menyatakan: "Kalau kita dengan rasa penuh tanggung jawab kepada Islam-berusaha memahami ajaran Islam yang luhur itu dengan memanfaatkan akal budi, maka kita bukan yang pertama yang berbuat demikian. Dan hanya dengan meneladani keberanian Umar bin Khatab itu umat Islam tidak akan kedodoran dalam menyongsong abad 21 mendatang dengan perkembangan hidup yang amat pesat nanti (Sjadzali, 1997: 77-78)."

Abdurrahman Wahid, yang sering dipangil Gus Dur, dalam upaya pribumisasi Islam, mengimbau agar kita menghargai budaya, sebanyak mungkin menyerap adat dan budaya lokal ke alam Islam. Artinya pehaman terhadap nas dikaitkan dengan masalah-masalah aktual di Indonesia. Sebagai contoh, secara budaya Assalamu'alaikum adalah sekedar ucapan berbaik-baik, jika bertemu orang. Karena itu, secara budaya, ucapan salam itu bisa digantikan dengan selamat pagi dan sebagainya. Akan tetapi harus diingat bahwa di dalamnya terdapat dua persoalan yang menyangkut norma. Pertama, memulai salam memang tidak wajib, tetapi menjawabnya adalah kewajiban sehingga ucapan itu tidak bisa digantikan dengan ucapan selain yang telah ditetapkan. Kedua, ucapan salam merupakan bagian tak terpisahkan dari salat (Qomar, 2002:176).

Masdar Farid menegaskan: "Pada dasarnya tidaklah ada Shari'at yang bersifat mutlak, dan secara apriori berlaku untuk segala ḍurūf (waktu, tempat dan keadaan). Sebagai jalan atau cara bagaimana suatu tujuan dicapai, Shari'at mestilah bersifat dinamis dan kontekstual. 
Satu paket Shari'at yang cocok untuk mencapai tujuan dalam suatu ḍurūf sosial tertentu dengan serta merta cocok untuk mencapai tujuan yang sama dalam ḍurūf yang berbeda. Ini berlaku bukan saja hanya untuk Shari'at yang dirumuskan sendiri oleh manusia, tetapi juga mengena pada Shari'at yang ditawarkan oleh Tuhan sebagai ekspresi rahmat-Nya yang berlimpah kepada manusia. Sesungguhnya prinsip relativitas dan kontekstualitas Shari'at ini sangatlah jelas. Dalam al-Qur'an, prinsip tersebut diakui secara eksplisit dalam ayat yang berbunyi; Li kullin ja'alnā min-kum shir'ah wa minhäj. Untuk masing-masing kalian (selaku komunitas yang berbeda), kami canangkan Shari'at dan metode yang juga berbeda. Akan tetapi, lantaran kerangka pemahaman keagamaan yang dogmatis-formalistis seperti diungkapkan di atas, prinsip kontekstualitas yang sejelas itu menjadi kabur dan atau dikaburkan. Akibatnya, apa yang sebenarnya relatif telah dimutlakkan, dan yang sebenarnya dinamis telah distatiskan. Shari'at yang berarti jalan dan cara (wașilah) untuk mencapai tujuan, telah diberi derajat kemutlakan seperti halnya tujuan (gayah) (Qomar, 2002: 201).

Hendaknya selalu dipahami bahwa bangunan pemikiran fiqh yang fundamental adalah kemaslahatan, kemanusian universal atau keadilan sosial. Tawaran ijtihad apapun, baik didukung dengan nas atau tidak, yang mampu menjamin kemaslahatan kemanusian dalam kacamata Islam adalah sah dan umat Islam terikat untuk merealisasikan. Karena itu, kata Agiel Sirodj harus ada suatu pembaharuan yang menggunakan pemikiran rasional yang disandarkan pada ketentuan naș. Pemahaman terhadap ketentuan nas itulah yang harus dikembangkan dengan mengoreksi pemahaman lama. Ketentuan naș baik dari al-Qur'an maupun al-hadis yang dipandang qați oleh ulama tertentu bisa jadi hanya zaanni oleh ulama lain. Begitu juga nas yang dipandang qaț’i pada masa tertentu menjadi zanni pada masa yang lain karena perubahan setting sosial, ilmu pengetahuan dan teknologi. Lebih dari itu mungkin saja terjadi bahwa suatu nas mengandung aspek qaț’i dan zanni sekaligus. Karena itu dalam berijtihad untuk mengambil kesimpulan hukum perlu diperhatikan maqāṣid al-Shari’ah, agar hukum tidak sekedar demi hukum. Tiada lain tujuan hukum itu ialah demi keadilan, kemaslahatan, mencegah timbulnya kemadaratan dan kerusakan

Sahal Mahfudh, dalam beberapa tulisannya seperti Menggagas Fiqih Sosial, dia sering memahami pendekatan maṣlahah sebagai pertimbangan terdepan dalam proses pengambilan keputusan. Gagasan ini pada akhirnya dikukuhkan dalam muktamar NU di Cipasung dengan 
masuknya maṣlaḥah sebagai pertimbangan utama dalam keputusan-keputusan komisi masāì diniyah (Qomar, 2002: 242).

Dari kalangan modernisme Islam seperti Nurcholis Majid, Usep Fathuddin, Utomo Dananjaya, Djohan Effendi dan Dawan Rahardjo merasakan adanya ketidakmampuan sebagian kaum muslimin untuk membedakan nilai-nilai transendental dengan nilai-nilai temporal. Sering kali terjadi nilai-nilai yang sebetulnya merupakan sesuatu bersifat zanni-ijtiba $\bar{a} \bar{i}$ diberlakukan sebagai hal yang qat'i dan sakral. Sementara yang bersifat sakral seperti nilai, moral dan etika seringkali diberlakukan sebagai sesuatu yang profan (Haryono, 2002 :227).

Ideologi ijtihad kalangan Islam modernis pada fikih kemanusiaan ini bertumpu pada 3 hal. Pertama, mengambil posisi ijtihad bebas sebagai sesuatu yang sepenuhnya secara eksplisit didukung oleh Shari'ah sejalan dengan kemaslahatan manusi. Kedua, kaum muslimin bebas untuk mengambil sikap netral dalam sesuatu hal yang dibiarkan terbuka oleh Shari'ah dan diberikan otonom bagi mujtahid sejalan dengan maqāasid al-hukmu untuk berpendapat sesuai dengan akal budi dan kecerdasan manusia (silent Shariah). Ketiga, syariah bersifat Ilahiah dan ditujukan bagi penafsiran penafsiran manusia yang beragam (interpreted Shari’’ah). Bagi kelompok ini bahasa al-Qur'an berkoordinasi dengan esensi dari wahyu, namun isi dan makna dari wahyu tidaklah esensial bersifat verbal melainkan perlu penafisran sesuai konteks budaya dam masyarakatnya.

Kata-kata al-Qur'an tidaklah mencakup seluruh pemahaman makna tentang wahyu Tuhan, sehingga memerlukan upaya untuk memahami apa yang menjadi dasar dari bahasa wahyu tersebut. Untuk membawa wahyu ke dataran praksis perlu penafsiran secara integral yang berhubungan dengan esensi wahyu, konteks historis, ruang dan waktu berdasarkan penafsiran rasional untuk mencari solusi yang tepat yang berpihak pada kepentingan rakyat. Dibolehkan untuk menciptakan teks-teks baru berdasarkan pergulatan dari berbagai identitas pengetahuan maupun kemampuan kita dalam merekontruksi keberagaman Islam yang khas budaya Indonesia (Pribadi, 2002 :227).

Dari uraian di atas dapat dipahami bahwa pemikiran al-Tufi berpengaruh secara langsung seperti Munawir Sjadzali dan Ibrahim Hosen maupun tidak langsung seperti kalangan para cendikiawan muslim di Indonesia dalam pengembangan kontekstualisasi hukum Islam sehingga sangat dinamis. Dalam pengembangan hukum Islam di Indonesia dari kalangan 
mereka itu ada yang bersifat antisipatif dengan menunjukkan tantangan masa depan serta memberikan solusinya; ada yang bersifat elektif sehingga maṣlahah sebagai pertimbangan terdepan dalam menetapkan hukum Islam; ada yang bersifat konseptual dengan mengkirik metodologi hukum Islam disertai memilih menggunakan maṣlaḥah versi imam Malik; ada yang bersifat divergen karena liberasi pemikirannya sering mangadakan lompatan-lompatan pemikiran, ada yang bersifat integralistik dengan lebih memilih hubungan yang harmonis antara nas dan realitas; dan ada yang bersifat responsif yang peka untuk memberikan jawaban terhadap keresahan umat yang telah dan sedang terjadi

\section{Fikih Islam dalam proses modernisasi dan perubahan sosial}

Kehadiran al-Tufi sebagai salah satu ulama intelektual-genius, dan penulis produktif yang bergaya liberalis pada masa itu sangat berarti kaitannya dengan pembukaan pintu ijtihad. AlTufi adalah salah satu fuqahā yang berusaha membuka pintu ijtihād seluas-luasnya yang selama itu masih terkesan tertutup rapat dengan menempuh maz̧ hab manhaji, bersikap moderat dengan mengembangkan ibyā' al-fikrah al-Istamiyyah wa al-ijtihäd al-mașlahah.

Implementasi ijtihād al-Tufi bukan saja ijtihād yang bersifat bayāni dan qiyāasi, melainkan

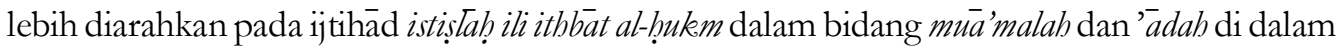
rangka menyelaraskan kehidupan Islam sesuai dengan ajaran agama dalam realitas kekinian.

Ijtihād istiṣlāhi diimplementasikan karena sesungguhnya hukum-hukum yang ditetapkan oleh Allah dalam al-Qur'an maupun oleh Rasulullah pada dasarnya li mașaliḥ al-'ibād. Seorang mujtahid yang melakukan ijtihad adalah benar, karena hukum Allah tidak satu, tetapi mengikuti dugaan orang yang melakukan ijtihad. Hukum Allah berada dalam hak setiap mujtahid sesuai dengan hasil dugaan ijtihadnya (Al-Amidy,t.t: 246). Dalam pada itu, maqāsid al-ḥukm sudah seharusnya menjadi acuan mujtahid dalam ithbät al hukm. Ketentuan hukum apa saja yang ditetapkan berdasarkan ra'yu mujtahid sesungguhnya bukanlah mengeluarkan hukum ciptaan mujtahid. Ia hanya menemukan, melahirkan dan mengeluarkan hukum, seperti ketika kita menciptakan sesuatu, pada hakikatnya pencita itu adalah Allah swt.

Penetapan hukum berdasarkan metode istislāhi bi al'ra'yi bisa saja dinilai kontradiksi dengan nas yang bersifat qat'i. Tetapi melalui pendekatan hermeneutik dengan menyadari al-Qur'an tidak terlepas dari historisitasnya, bukan suatu hal yang absurt nas qat’i termasuk wilayah ijtihā $\overline{d i}$. 
Atas acuan tujuan hukum dengan pendekatan hermeneutik ini, pernyataan al-Tufi bahwa maṣlaḥah sumber hukum tersendiri lepas dari nas, dimaksudkan limitasi ruang lingkup ijtihād yang selama ini hanya boleh pada wilayah naș zanni, perlu dikembangkan juga pada nas qaț $i$ sepanjang memenuhi kemaslahatan bagi manusia. Dengan demikian ruang lingkup ijtihād: Kullu nas majal al-ijtihäd walau käana șäiḥan qațiyyan al-dalalah.

Sisi lain bahwa maṣlaḥah sebagai sumber hukum yang berdiri sendiri lepas dari naș, mengisyaratkan bahwa bangunan sumber hukum fiqh yang fundamental adalah kemaslahatan, kemanusiaan dan keadilan sosial. Tawaran ijtihad apapun baik didukung dengan naṣ atau tidak, yang mampu menjamin kemaslahatan kemanusiaan dalam kaca mata Islam adalah sah dan harus ada kesungguhan kita untuk merealisasikannya. Kaidah yang ditawarkan: Iza șhhat al-maslaḥah fa huwa madh habi. Atas dasar ini segala hukum yang berorientasi kemaslahatan didasarkan pada realitas kemaslahatan masyarakat pada umumnya sehingga tidak terjebak pada penafsiran wahyu yang hanya berorientasi pada kemaslahatan sepihak, misalnya hanya terfokus pada kemaslahatan bagi para pengambil kebijakan seperti para penguasa. Dari sinilah sebenarnya al-Tufi mengimplementasikan konsep maṣlahah nya dalam bidang fiqh (hukum), sehingga persoalan kemaslahatan itu benar-benar menyentuh masyarakat kecil, bukan hanya berorientasi pada penguasa. Persoalan keadilan, persoalan pemerataan ekonomi, kesehatan, pendidikan, keamanan dan lain sebagainya benar-benar menyentuh dan membela kepentingan rakyat tertindas, mustad'afin. Seperti imam Nawawi menolak memberikan fatwa pengambilan dana dari seluruh rakyat Syam untuk biaya perang mempertahankan negara dari kemungkinan serangan bangsa Babar, dengan alasan karena rakyat sedang susah dan sengsara. Menurut pendapatnya anggota kerajaan saja yang harus megeluarkan biaya perang karena mereka telah cukup menikmati kekayaan yang melipah di mana dayang-dayang mereka saja berpakaian serba mewah bertahtakan emas dan intan berlian. Tidak seharusnya rakyat kecil yang kita peras, karena mereka sudah susah jangan ditabah kesengsaraannya (Zainuddin, 1992: 23-24).

Jadi, konsep fikih al-Tufi bukan didasarkan atas hukum legal-formal yang bersifat tektual yang cenderung memihak sehingga bersifat agresif dan reaksioner. Tetapi konsep fikihnya cenderung menisbikan labelisasi istilah agama, yakni mengoperasioanalisasikan ajaran agama yang substantif yang bersifat raḥmatan li 'al-älamin. Karena itu upaya yang dilakukan al-Tufi 
adalah penerapan nilai-nilai fikih Islam dalam proses modernisasi dan perubahan sosial dengan pendekatan yang lebih terbuka, dialogis dan konteks dengan acar budaya yang ada.

Mașlạah yang berdasarkan ra’yu ini bukan berarti ra'yu bebas tanpa landasan dan pijakan, melainkan berpijak pada adat dan realitas kemaslahatan manusia sebagaimana yang dipraktekkan para sahabat dan para imam mazhab seperti yang banyak dilakukan oleh Umar, ra. dan Imam Malik. Dalam hal ini metode yang dipakai berupa bayān, takhșis maupun taqyid dan tạ̣did al-nas. Dalam hal takhșiș masuk dibawah pengertian takhșiș munfasil. Karena itu ketetapan hukum yang berdasarkan maṣlaḥah tidak boleh terlepas dari maqāisid al-hukm. Itulah sebabnya al-Tufi dengan tegas membatasi berlakunya maṣlaḥah pada bidang mu'amalah dan adat, bukan pada bidang ibadah dan muqaddarat.

Ulama yang hidup memasuki masa modern sangat apresiatif terhadap al-Tufi yang telah berusaha menerapkan maṣlahah dalil mandiri lepas dari naṣ. Pada akhirnya banyak negaranegara yang aturan hukumnya didasarkan pada maṣlaḥah. Dengan meluasnya lingkup perubahan sosial yang mempengaruhi semua segi kehidupan, dimana filsafat utilitarian mulia menonjol, maka ulama Islam yang tergabung dalam gerakan modernisme berusaha mencari landasan atau pijakan sumber hukum Islam yang mampu mengilhami mereka menyesuaikan diri dengan kondisi yang berubah. Dengan demikian metode maṣlạ̣ah diharapkan mampu menjadi prinsip perubahan, elastisitas dan adaptabilitas fiqh dengan metode pemahaman fikih digeser dari paradigma kebenaran fikih ortodoksi (hitam putih) menjadi paradigma pemahaman fikih sosial (berwatak pemahaman bernuansa). Usaha-usaha yang dapat dilakukant antara lain: Pertama, berupaya terus interpretasi ulang dalam mengkaji teks-teks fikih untuk mencari konteknya yang baru sejalan dengan kemaslahatan yang ingin dicapai oleh tujuan hukum Islam, sehingga fikih tidak hanya berlaku pada hukum kekeluargaan, melainkan fikih mampu memberikan jawaban problem-problem sosial yang sedang dihadapi masyarakat (antisipatif).

Kedua, tidak ada upaya untuk naqd an-naṣ bi al-mașlaḥah; melainkan tabdil untuk merelevansikan dan memberikan alternatif-alternatif hukum yang lain sejalan dengan konteksnya; sebab tidak mungkin ada maṣlaḥah hakikiyah bertentangan dengan nas qat'i. Nas qat’i itu identik dengan maṣlaḥah hakikiyah. Ketika ada maṣlaḥah dinyatakan bertentangan dengan nas harus dicari dalālahnya yang sejalan dengan hukum adat yang berlaku sebagaimana 
praktek imam Malik.

Ketiga, makna bermaz̧hab diubah dari cara bermaz̧hab tekstual yang berwatak hitamputih yang melahirkan ta'asssub ke arah bermazhab mutlak secara metodologis (madhbab manhaji) yang berwatak ijtihadidi. Tolak ukur validitas paham keagamaan bukan dari sudut penalaran murni akal maupun teks ajaran (nas) melainkan kenyataan sejauhmana paham itu mampu menjamin keadilan, kemanusiaan dan kemaslahatan manusia di dunia dan akhirat (eklektik).

Keempat, verifikasi mendasar, mana hukum yang pokok (usü) dan mana yang cabang (furü), diletakkan di mana qat' $i$ dan z̧anninya dan mana yang strategis dan mana yang aplikatifteknis sehingga maqāsid al hukm tercapai.

Kelima, harus ada penyadaran bahwa istilah keqat'iyyan dan ke-zanniyan nas adalah sebuah ketentuan dari para ahli usūl, karena itu ketentuan nas ini qat'i dan nas itu danni adalah bukan suatu kepastian, karena para ulama ușūl sendiri ada perbedaan mengenai batasan qat’i dan tidaknya nas.

Keenam, fikih dihadirkan sebagai etika sosial (kontrak sosial) yang mengakar pada budaya masyarakat, bukan semata-mata sebagai hukum positif negara yang kering dari rasa keadilan dan kemaslahatan.

Ketujuh, mengupayakan metodologi hukum Islam dengan mengedepankan pemikiran filosofis dan rasional bahwa masalah-masalah hukum tidak terlepas dari masalah budaya dan sosial, sehingga mampu menempatkan maslaḥah sebagai sumber hukum pada posisi yang sahih sejalan dengan kaidah-kaidah syara' dan maqāșidnya.

Kedelapan, pemahaman teks hukum tidak mungkin dapat dilakukan secara baik jika terpisah dari kehidupan manusia. Pemahaman teks hukum akan dapat dilakukan secara baik apabila terjadi dialog, hubungan keserasian yang harmonis antara tiga unsur yang saling terkait: nas agama, akal dan tradisi hidup berikut kasus-kasus yang terjadi di dalamnya (integralistik).

Kesembilan, mengupayakan implementasi nilai-nilai fikih ke dalam pembaharuan hukum Islam sejalan dengan proses modernisasi dan perubahan sosial dengan pendekatan yang lebih terbuka, dialogis dan kontekstual, (responsif). Di sini perlu dipertimbangkan keberadaan budaya sebagai bagian integral dari kehidupan masyarakat, sehingga memudahkan membumikan fikih menjadi adat kebiasaan. 
Ijtihad, Jurnal Wacana Hukum Islam dan Kemanusiaan, Volume 14, No. 2, Desember 2014: 167-187

Kesepuluh, dengan menghadirkan fikih melalui paradigma pemahaman sosial, maslaḥah sebagai sumber hukum sangat penting dalam membentuk fikih menjadi etika sosial yang mengakar dalam masyarakat, lebih-lebih dalam upaya legalisasi fiqh yang dituangkan dalam undang-undang positif.

Kesebelas, persoalan dan tantangan yang dihadapi fikih sangat kompleks dan membutuhkan banyak segi untuk dapat menimbang antara maṣlaḥah dan maḍaratnya. Karena itu dalam berijtihad perlu melibatkan sejumlah pakar yang mempunyai keahlian yang berbeda-beda, tetapi saling mengait dalam menemukan kebenaran pemecahan masalah hukum yang terjadi. Untuk menjamin kualitas solusi fikih yang ditawarkan sebagai suatu kebenaran yang bersifat manusiawi, perlu dilakukan secara kolektif sehingga kebenarannya diakui dari berbagai sudut pandang keilmuan dan keahlian.

Keduabelas, pilihan yang paling ideal dan paling sesuai dalam hal ini adalah ijtihad kolektif (jama'i). Sementara metode talfi $q$ sebagai salah satu metode penerapan hukum Islam pada hal-hal tertentu, menjadi salah satu alternatif untuk menjawab persoalan yang ada yang dituangkan dalam bentuk perundang-undangan. Misalnya konstitusi pertama Tunisia dalam preambulnya menekankan bahwa mașlaḥah harus dirujuk sebagai penafsiran hukum yang bisa memberikan keadilan sebagai jaminan pelestarian ketertiban dunia, dengan prinsip adanya kebebasan, keamanan dan persamaan. Khoeruddin Pasha di Pakistan menjadikan mașlahah sebagai pedoman tertinggi pemerintah. Hal ini sangat penting kaitannya dengan perubahan lembaga-lembaga hukum demi kepentingan umum, sebaliknya ia menentang keras adanya perubahan yang tidak sejalan dengan kemaslahatan umum. Muhammad Abduh menekankan bahwa pembaharuan-pembaharuan peradilan di Mesir dan Sudan harus dikembalikan pada maṣlaḥah sebagai prinsip dasar pembuatan hukum.

Konsep maslạ̣ah al-Tufi yang cukup kontroversial telah mempengaruhi perubahan wawasan, sikap dan kesadaran para cendikiawan dan ulama, khususnya ulama figh dalam menghadapi tuntutan-tuntutan zaman yang makin kompleks. Dewasa ini telah lahir cendikiawan dan ulama modernis dan kalangan tradisionalis progresif dan kreatif di dalam pengembangan hukum Islam. Telah tumbuh rūḥ al-intiqä $i$ (sikap kritis mempertanyakan) dari kalangan ulama baik yang tua maupun yang muda sehingga menjadi progresif. Lahirlah beberapa undang-undang maupun fatwa ulama yang mengutamakan maṣlaḥah sebagai 
pertimbangan hukum pertama. Bahkan dari sisi metodologis, pembentukan undang-undang maupun fatwa ulama ada yang tidak memberlakukan nas, kalau tidak dikatakan membatalkan nas, mengutamakan pertimbangan rasional. Mengutamakan teks fiqh dan sistem pengambilan maraji’nya bukan sekedar memilih salah satu mazhab 4 tetapi maẓhab manapun yang dipandang keputusan hukumnya lebih maṣlahạah akan diambilnya seperti maẓhab ḍāhiri dan maẓhab lainnya.

Mujtahid yang mencoba mengotak-atik nas, bahkan meninggalkan nas dengan cara mendahulukan maṣlaḥah dalam usaha iṣtinbāt hukum ternyata mendapatkan dukungan dari ulama-ulama tertentu. Hal ini menandakan adanya kesadaran untuk menerima perubahan dan pembaharuan hukum Islam bidang mu'amalah seperti hukum keluarga, ekonomi, sosial, politik dan ketatanegaraan melalui pembaharuan metodologinya dan melalui pertimbangan rasional. Pada waktu yang sama dengan cara tabyīn, taḥdid, taqyid dan takhșiș ketentuanketentuan hukum mu'amalah akan mengalami pergeseran dalam bebentuk tajdìd al-ḥukm dan tabdìl al-ḥukm.

Seperti yang dilakukan MUI dalam mengambil putusan hukum banyak mengeluarkan fatwa yang oleh banyak kalangan dinilai sangat dinamis. Fatwa MUI tanggal 1 Juni 1980 tentang seorang wanita Islam tidak diperbolehkan (haram) untuk dinikahkan dengan seorang pria bukan Islam, dan seorang laki-laki muslim tidak diijinkan menikahi seorang wanita bukan Islam adalah di luar teks Al-Qur'an dan bertentangan dengan teks fikih klasik yang sepakat memberi ijin kepada seorang laki-laki muslim untuk menikahi seorang perempuan dari abl al-kitāb (Mudzhar,1993: 100).

Fatwa MUI 23 Maret 1978 yang berkaitan dengan peredaran film Adam and Eva, dan The Message, bahwa majlis tidak berkeberatan terhadap impor dan pertunjukan film itu kepada masyarakat umum. Fatwa ini dikeluarkan setelah dilihat di dalam film itu tidak memuat gambar Nabi Muhammad. Dalam fatwa ini sama sekali tidak merujuk pada al-Qur'an, hadis ataupun teks fiqh dan tafsir. Dan tidak juga berisi dalil apapun yang bersifat rasional

Rekomendasi MUI tentang jual beli tanah waris yang berukuran kecil, adalah lepas dari naṣ yang ada, hanya semata-mata bersandarkan maṣlaḥah. MUI pada tahun 1984 merekomendasikan bahwa adalah lebih baik jika tanah-tanah warisan yang ukurannya kecil tidak dibagi-bagikan di antara para ahli waris, melainkan dibiarkan utuh sebagai satu kesatuan 
yang hasilnya dapat dinikmati bersama oleh para ahli waris. Jika hal ini tidak mungkin dilaksanakan, misalnya salah seorang ahli waris sangat memerlukan uang, maka disarankan agar tanah itu dijual kepada ahli waris lainnya. Apabila hal ini masih juga tidak mungkin dijalankan karena tidak ada ahli waris yang mampu membeli tanah warisan tersebut, maka dianjurkan supaya tanah itu dijual kepada pemilik tanah di sekitarnya. Kalau tidak bisa dilakukan, maka hendaknya ditawarkan ke umum dari desa yang sama yang beragama Islam (Mudzhar, 1993: 107-108).

Dalam Undang-Undang perkawinan No 1 tahun 1974 banyak pasal-pasal yang nampak secara lahiriyah berbeda dengan nas baik, al-Qur'an, hadis maupun teks fikih. Dan sumber pengambilan hukumnya tidak hanya terbatas pada mazhab 4 saja, bahkan banyak diambil secara talfiq . Misalnya Seorang suami dinilai sah menjatuhkan talak hanya di depan hakim Pengadilan Agama (ps.39). Hakimlah yang menyatakan keabsahan penjatuhan talak itu. Jadi pengucapan talak oleh seorang suami di rumah atau melalui surat baru menunjukkan keinginan menceraikannya, belum sah menurut hukum. Tentang anak, anak yang sah adalah anak yang dilahirkan dalam atau sebagai akibat perkawinan yang yang sah (ps.42) UU Perkawinan No 1 tahun 1974) Di sini tidak bicara soal proses anak, sehingga anak yang diproses sebelum perkawinan asal nanti lahir dalam perkawinan yang sah nilainya menjadi anak sah. Dan masih banyak lagi undang-undang yang proses pengambilan hukumnya lepas dari nas, atau hanya berdasarkan teks fikih dan itupun tidak terikat mazhab empat, bahkan banyak yang pengambilan keputusannya berdarkan talfiq. Seperti undang-undang no 13 tahun 2008 tentang penyelenggaraan ibadah haji, undang-undang no 23 tahun 2011 tentang pengelolaan zakat, undang-undang no 41 tahun 2004b tentang wakaf dan lainnya.

\section{Penutup}

Ijtihad fikih melalui metode mașlạ̣ah yang dikembangkan al-Tufi bukan didasarkan atas hukum legal-formal yang bersifat tekstual yang cenderung memihak sehingga bersifat agresif dan reaksioner. Tetapi konsep fikihnya cenderung menisbikan labelisasi istilah agama, yakni mengoperasionalisasikan ajaran agama yang substantif yang bersifat raḅmatan li 'al-älamin, dengan menempatkan nilai-nilai fikih Islam dalam proses modernisasi dan perubahan sosial. Hal ini bertujuan untuk menjauhkan konsep fikih yang bersifat imperatif dan teistik saat itu, 
dengan mengarahkan cara pandang fikih yang bersifat teologis- bumanistis, dimana segala perintah Allah swt. sebagai refleksi kasih sayang-Nya atas kepentingan kemaslahatan manusia

Dari sinilah sebenarnya al-Tufi mengimplementasikan metode maṣlaḥah nya dalam bidang figh (hukum), sehingga persoalan kemaslahatan, khususnya bidang mu'amalah dan adat benar-benar menyentuh masyarakat kecil. Al-Tufi menghadirkan fikih sebagai etika sosial (kontrak sosial) yang mengakar pada budaya masyarakat, sehingga ia berupaya mengimplementasikan nilai-nilai fikih sejalan dengan proses modernisasi dan perubahan sosial dengan pendekatan yang lebih responsif, integral, terbuka dan kontekstual berdialog dengan kehidupan masyarakat, sehingga memudahkan membumikan fikih sejalan dengan akar budaya bangsa.

Konsep maṣlaḥah al-Tufi -seiring dengan hermeneutika sebagai salah satu metode penafsiran al-Qur'an - menjadi akar yang kuat pada gerakan-gerakan modernisme Islam dan gerakan pembaharuan hukum Islam baik di dunia Islam maupun di Indonesia. Mereka mencurahkan perhatian ilmiahnya untuk mengkaji metode maṣlaḥah sebagai landasan atau pijakan yang mampu membantu mereka menyesuaikan diri dengan kondisi-kondisi yang berubah. Tawaran ijtihad baik didukung dengan nas atau tidak, yang mampu menjamin kemaslahatan kemanusian dalam kacamata Islam adalah sah dan harus ada upaya untuk merealisasikannya. lewat jalur ini, Ijtihad fikih akan lebih responsif berbicara persoalan keadilan, persoalan pemerataan ekonomi, sosial, politik, kesehatan, pendidikan, keluarga, ketatanegaraan, keamanan dan lain sebagainya yang benar-benar menyentuh dan membela kepentingan penegakan budaya bangsa dengan memasukkan nilai-nilai fikih ke dalamnya tanpa labelisasi Islam secara terbuka.

\section{Daftar pustaka}

Al-Amiri, Abdallah M. al-Husein. Al-Tufi's Refutation of Traditional Moslem Juristic of Law and his view on the priority of Regard of Human Welfare as the Highest Legal Source of Principle. Quibec: McGill University, 1993.

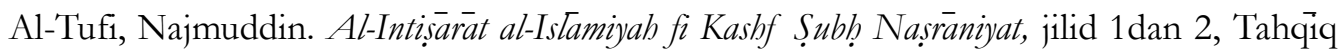
Salim Ibn Muhammad al-Qarni. Al-Riyad: Maktabah al-Abikan, 1999.

Al-Tufi, Najmuddin. Al-Ishärah al-Ilähiyyah ila al-Mabähith al-Ușüliyah, jilid 1,2,dan 3 Tahquiqu, Abu Asim Hasan ibn Abbas ibn Qutub. Makkah: al-Maktabah al-Makkiyyah, 2002. 
Ijtihad, Jurnal Wacana Hukum Islam dan Kemanusiaan, Volume 14, No. 2, Desember 2014: 167-187

Al -Tufi, Najmuddin. Al-Ta'yin fi Sharḥi al-Arbāin Al-Nawawi, Tahqīi, Ahmad Haji Muhammad Usman. Makkah: al Maktabah al-Makkiyyah, 1998.

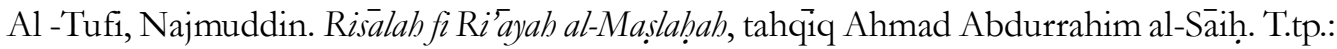
al-Dār al-Mișriyyah li al-Banāniyah, 1993.

Al -Tufi, Najmuddin. Sharah Mukhtașar Raudah, jilid 1,2 dan 3, Tahqiq Abdullah Al-Muhsin at-Turki. Bairut: Al-Risālah, 1998.

Al -Tufi, Najmuddin. Sharh al Arba'in al-Nawawi, Mulbiq al Mașlạ̣ah fi at Tashri' al-Islami. Kairo: Dār al Fikr al- 'Arabi, 1945.

Al-Tufi, Najmuddin. Al-Bulbul fi Ușul al-Fiqh, cet ke-2. Riyaḍ: Maktabah Imam al-Shāfīī, t.th.

Braaten, Carl. History of Hermeneutics. Philadelpia: Fortiess, 1966.

Al-Buti, Said Ramḍan. Dawäbit Al Maslahah fi Al-Sharīah al Istamiyah. Beirut: Muassasah alRisālah, 1977.

Dahlan, Abdul Aziz, dkk. Suplemen Ensiklopedi Islam, jilid 2 Cet ke-3. Jakarta: Ikhtiyar Baru, Van Hoeve, 1999.

Esack, Farid, “Qur'anic Hermeneutics: Problem and Prospects”, The Moslem World, Vol. 83, No. 2 (1993).

Al- azali, Abu Hamid. Al-Mustaş̧⿻ min Tlm Ușül, juz 2. Kairo: t.p., 1937.

Hasan, Husein Hamid. Naz̧ariyah al-Mașlaḥah fi al-Fiqh al-Islami- Beirut: Dar al-Nahḍah al'Arabi, 1971.

Hazm, ibnu. Al-Fasl fi al-Ahwa' wa al-Niḥal, jilid 5. Kairo: Ali Subih, 1964.

Kerr, Malcolm H. Islamic Reform, the Political and Legal Theories of Muhammad Abduh and Rashid Rida. Los Angeles: University of California Press, 1996.

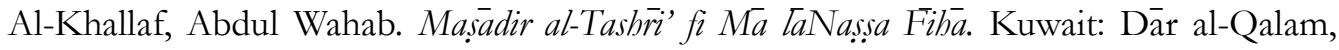
1972.

Mahfudh, Sahal. Nuansa Figh Sosial. Yogyakarta: LKiS, 1994.

Al-Maragi, Abdullah Mustafa. Pakar-pakar Fiqih Sepanjang Sejarah. Yogyakarta: LKPSM, 2001.

Mas’udi, Masdar Farid. Agama Keadilan: Risalab Zakat (pajak) dalam Islam. Jakarta: Pustaka Firdaus, 1993.

Mudzhar, Muhammad Atho. Fatwa-Fatwa Majlis Ulama Indonesia: Sebuah Studi tentang Pemikiran Hukum Islam di Indonesia 1975-1988. Jakarta: INIS, 1993.

MUI. Himpunan Fatwa Majlis Ulama Indonesia. Binbaga Islam, Depag, 2003.

Nafis, Muhammad Wahyuni dkk. Kontekstualisasi Ajaran Islam 70 tabun Prof. Dr. Munawir Sjadzali, M.A. Jakarta: Kerjasama IPHI- Paramadina, 1996. 
Menempatkan nilai-nilai fikih Islam dalam proses modernisasi dan perubahan sosial...(Saifudin Zuhri)

Pribadi, Airlangga dan M.Yudhi R. Haryono. Post Islam Liberal. Jakarta: Pasirindo Bungamas Nagari, 2002.

Qomar, Mujamil. NU Liberal: Dari Tradisionalisme Ablussunnah ke Universalisme Islam. Bandung: Mizan, 2002.

Rahman, Budi Munawar (ed). Kontekstualisasi Doktrin Islam Dalam Sejarah. Jakarta: Paramadina, 1994.

Shihab, Quraish. Membumikan al-Qur'an. Bandung: Mizan, 1992.

Al-Siqati, Salim Ali. Mafatih al-Fiqh al-Islämi al-Hanbali, Jilid 1. tk.: tp., 1978.

Sjadzali, Munawir. Reaktualisasi Ajaran Islam. Jakarta: IPHI kerjasama dengan Paramadina, 1995.

Sjadzali, Munawir. Ijtihad Kemanusiaan. Jakarta: Paramadina, 1997.

Undang-Undang Perkawinan, Surabaya: Karya Anda, t.th.

Yafi, Ali. Fiqih Sosial. Mizan: Bandung, 1997.

Zahrah, Abu. Ușül Fiqh. Kairo: Dār al-Fikr al-'Arabì, t.th.

Zaid, Farauq Abu. Hukum Islam antara Tradisionalis dan Modernis. Jakarta: P3 M, t.th.

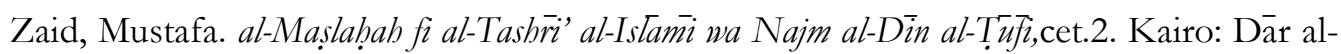
Fikr al-'Arabi, 1964. 